\title{
Phenotypic characterization and production potentials of Nageswari duck in Bangladesh
}

\author{
M. Morduzzaman', A.K.F.H. Bhuiyan', M. Rana², M. R. Islam³, M. S. A. Bhuiyan ${ }^{1 *}$ \\ ${ }^{1}$ Department of Animal Breeding and Genetics, Bangladesh Agricultural University, Mymensingh-2202, \\ Bangladesh; '2Scientific Officer, Poultry Production Research Division, Bangladesh Livestock Research Institute, \\ Savar, Dhaka; ${ }^{3}$ Poultry Development Officer, Central Duck Breeding Farm, Narayanganj
}

\begin{abstract}
The present study was conducted to know the morphology, morphometry, production and reproduction potentialities of Nageswari duck, an indigenous duck genetic resource of Bangladesh. Data on 58 representative adult Nageswari ducks were included for morphological study from 24 duck owners and two government organizations having Nageswari duck flocks while 468 individuals were considered for the traits of productive and reproductive performances. Information was collected by using a structured questionnaire through personal interaction, on spot recording and direct phenotypic measurements in five different regions of Bangladesh. Black plumage color with white stripe extended from neck to breast make unique features of Nageswari duck compared to other indigenous ducks. Morphometric measurements on adult live weight, body length, head diameter, bill length, neck length, shank length, wing length, massiveness and condition index in male and female were found to be $1.66 \pm 0.07$ and $1.51 \pm 0.05 \mathrm{~kg}, 26.27 \pm 0.57$ and $23.79 \pm 0.39 \mathrm{~cm}, 3.49 \pm 0.02$ and $3.36 \pm 0.04 \mathrm{~cm}, 5.87 \pm 0.09$ and $5.54 \pm 0.07 \mathrm{~cm}, 23.49 \pm 0.58$ and $21.59 \pm 0.49 \mathrm{~cm}, 5.76 \pm 0.12$ and $5.16 \pm 0.11 \mathrm{~cm}, 24.58 \pm 0.49$ and $21.99 \pm 0.53 \mathrm{~cm}, 6.33 \pm 0.28$ and $6.39 \pm 0.22$, and $6.72 \pm 0.23$ and $6.93 \pm 0.23$ respectively. Age at first egg of Nageswari duck was found to be $168.48 \pm 3.53$ days. Total number of eggs laid per year averaged $173.63 \pm 3.39$ and peak production was found in $29.46 \pm 0.19$ weeks. The average egg weight was estimated to be $67.32 \pm 0.82 \mathrm{~g}$ and characteristic bluish tinge of egg color was observed. Breed specific characteristic features and production profiles were observed in this study. The present study provided some baseline information on Nageswari duck of Bangladesh which could be useful for genetic characterization, conservation and future improvement programs in Bangladesh.
\end{abstract}

Key words: Nageswari duck, Phenotype, morphometric, production, reproduction,

Bangladesh Animal Husbandry Association. All rights reserved.

Bang. J. Anim. Sci. 2015. 44 (2): 92-99

\section{Introduction}

Ducks are considered as the second most preferred poultry species in Bangladesh after chicken used for egg and meat purposes. Duck population in Bangladesh has been reported to be 45.12 million (BER 2012), mostly of indigenous type. The contribution of duck meat and eggs are about $30 \%$ of the total poultry meat and eggs produced in the country (Islam et al. 2003). Farmers prefer indigenous ducks in extensive rearing system due to high adaptability to their farming conditions, unique foraging and disease resistance. They possess several attributes over chicken like prolificacy and produce 15-20 more eggs than backyard chicken. Ducks have long productive and profitable life i.e., they continue to lay until third year. Marshy, swampy river side, wet lands and barren lands are not suitable for chicken rearing but are suitable for duck rearing (Valavan et al. 2009). The distribution pattern and demographic dynamics of duck population in Bangladesh revealed that land ecology has a strong influence on duck production systems (Khanum et al. 2005). Traditionally every household keep just a few ducks in association with chicken throughout the country. However, large scale commercial duck farms are available in haor areas with flock size ranging from around one hundred to more than one thousand.

Nageswari, an egg type indigenous duck breed, is found to be distributed in the Barak valley of Assam bordering Meghalaya, Tripura, Mizoram 
and adjacent regions of Bangladesh (Islam et al. 2002). The original homeland of this duck breed is believed to be the then Sylhet district of Assam, which was later embodied now in Bangladesh (Zaman et al. 2005). The local name of Nageswari ducks are 'Nagi' or 'Nagin', the snake deity, may be due to its head-high snake like posture with a white stripe in the neck extending up to the breast and for the eggs which have a bluish tinge. They are also called White Breasted Nageswari while the rest of the plumage color black or pencilled black.

The average annual egg production of Nageswari ducks ranged between 120-150 numbers (Islam et al. 2002; Sharma et al. 2003). Authors also mentioned their productivity of 200-220 eggs per year under intensive management condition (Valavan et al. 2009). On the contrary, indigenous ducks of Bangladesh produce only 6080 eggs per year (Rahman et al. 2009) which signifies the genetic potentials of Nageswari duck. However, over the years, indiscriminate crossbreeding with Indian Runner, Khaki Campbell, Jinding and lack of scientific management has eroded this valuable germplasm in Bangladesh. It is hard to find them now in their place of origin despite they are dispersedly distributed in North Eastern districts of Bangladesh (personal communication).

Characterization of a breed/species is the first and foremost priority to know the population structure, effective conservation plan and utilization of genetic resources. Nageswari ducks are in vulnerable state in Bangladesh due to unplanned crossbreeding with exotic duck breeds as well as absence of breeding scheme for this valuable germplasm under in situ management condition. In fact, the genetic potentials and demographic distribution of this breed is even unknown to livestock personnel. Furthermore, there is lack of scientific documentation on their phenotypic features, productive, reproductive and disease aspects of this genetic resource in Bangladesh. Therefore, the study was designed to investigate the morphological features, productive and reproductive performances of Nageswari duck of Bangladesh.

\section{Materials and Methods}

Preliminary information on the availability and concentration of Nageswari ducks were collected from livestock stakeholders as well as duck farmers. Based on the acquired information, data were collected from randomly selected 11 Nageswari duck farmers from Bhurungamari and Sadar upazilas of Kurigram; 12 farmers from Nandail, Iswarganj, Gauripur and Mymensingh Sadar upazila and 01 from Nikliupazila of Kishoreganj district during May 2014 to November 2014. In addition, Nageswari duck flocks of Central Duck Breeding Farm (CDBF), Narayanganj and Bangladesh Livestock Research Institute (BLRI), Savar, Dhaka, was also included in this study. A structured questionnaire was prepared, pre-tested and used for data collection. Finally, 24 Nageswari duck owners and personnel's of 2 government institutional flocks were interviewed comprising a population of 468 Nageswari ducks. In order to collect the relevant information, face to face interviewing and on spot recording were performed on duck population and genetic status, feeding regime, production potential, reproductive performance, phenotypic characteristics such as plumage color, shank color, skin color, eye color, bean color, bill color, web color, egg color, disease control and management practices. Quantitative data like egg weight, live weight at different ages and different morphometric measurements like shank length, bill length, neck length, head diameter, wing length and body length were measured on spot by using digital electric balance, measuring tape and slide calipers. The phenotypic features were observed, identified and documented properly.

Growth performance data of Nageswari ducks up to 12 weeks of age under intensive management system were collected from the flock record sheet maintained by BLRI. All collected information was tabulated in master table sheets. Before analyses, tabulated data were carefully checked and reviewed to detect any unusual or extreme values recorded and summarized in the sheet. Data were analyzed using Statistical Analysis System (SAS, version 9.1) to calculate descriptive statistics such as mean, standard error, range, frequency and percentage. 


\section{Characterization of Nageswari Duck of Bangladesh}

\section{Results and Discussion}

\section{Phenotypic characteristics}

The features of different phenotypic traits and their distributions are presented in Table 1 and in Figure 1. Neck, back, wing, tail and bean color in both male and female ducks were completely black. Head color in female ducks was black but white spotted head was found in some males (7.69\%). Breast color in male ducks was $84.62 \%$ white while it was $93.75 \%$ white in female ducks. Bill color was found to be yellowish (19.23\%), black $(57.69 \%)$ and black with yellowish tint $(23.07 \%)$ in male. In female, bill color found was black $(93.75 \%)$ and black with yellowish tint $(6.25 \%)$. Black and ash eye colors both in drakes and ducks were 88.46 and $84.37 \%, 11.54$ and $15.62 \%$ respectively. Web color found in ducks were $76.93 \%$ black and $23.07 \%$ black with yellowish tint in males and $87.50 \%$ black and $12.50 \%$ black with yellowish tint in females. All of these phenotypic observations about plumage color were similar with the findings of Sharma et al. (2002) and Zaman et al. (2005) with few exceptions in head, breast and bill color. This might be due to admixture of this breed with other available genotypes in their habitats. Egg color of Nageswari duck was bluish in color. This result is also supported by previous findings of Sharma et al. (2002) and Valavan et al. (2009).

\section{Morphometric measurement}

Different morphometric measurements of mature Nageswari ducks are presented in Table 2. The average body weight of adult male and female Nageswari duck were $1.66 \pm 0.07$ and $1.51 \pm 0.05$ $\mathrm{kg}$, respectively. These results are in agreement with the findings of Zaman et al. (2007) who reported adult body weight of Nageswari duck to be varied from 1.60 to $1.66 \mathrm{~kg}$ in males and 1.45 to $1.50 \mathrm{~kg}$ in females. However, relatively lower body weight was found by Sharma et al. (2003) in Nageswari duck. This might be due to difference in feeding and management practices. Body length was $26.27 \pm 0.57$ and $23.79 \pm 0.39 \mathrm{~cm}$ respectively in adult males and females. According to Murugan et al. (2009) body length of Sanyasi and Keeri variety of ducks in India were $32.73 \pm 0.14$ and $31.26 \pm 0.29 \mathrm{~cm}$, higher than the present study. This might be due to the difference between breeds. Head diameter was measured as $3.49 \pm 0.02$ and $3.36 \pm 0.04 \mathrm{~cm}$ in adult males and females of Nageswari ducks. Bill length averaged at $5.87 \pm 0.09$ and $5.54 \pm 0.07 \mathrm{~cm}$ respectively in adult males and females. Average neck and wing length were recorded to be $23.49 \pm 0.58$ and $24.58 \pm 0.49 \mathrm{~cm}$ in males and $21.59 \pm 0.49$ and $21.99 \pm 0.53 \mathrm{~cm}$ in females respectively. The present observations on head diameter, bill length and neck length were more or less similar with the finding of Murugan et al. (2009) and Vij et al. (2010). Murugan et al. (2009) reported that bill length and neck length of Sanyasi and Keeri variety of ducks of India were $6.81 \pm 0.82$ and $6.01 \pm 0.90 \mathrm{~cm}$, and $21.10 \pm 0.12$ and $18.70 \pm 0.24 \mathrm{~cm}$ respectively. $\mathrm{Vij}$ et al. (2010) also reported that head diameter and bill length of Deshi duck in West Bengal were $3.02 \pm 0.03$ and $5.25 \pm 0.04 \mathrm{~cm}$ respectively.

Average shank length was measured as $5.76 \pm 0.12 \mathrm{~cm}$ in males and $5.16 \pm 0.11 \mathrm{~cm}$ in female Nageswari ducks of the present investigation. Sharma et al. (2003) found shank length of male and female Nageswari duck at 20 weeks of age to be 6.49 and $6.16 \mathrm{~cm}$ respectively. In addition, Zaman et al. (2007) reported the shank length at 20 weeks of age in male and female Nageswari duck to be $6.67 \pm 0.71$ and $6.12 \pm 0.68 \mathrm{~cm}$ respectively. All of these observations were higher than the present findings which could be due to response to selection for this trait as well as difference in measurement method. Average massiveness and condition index in male and female was measured as $6.33 \pm 0.28$ and $6.39 \pm 0.22,6.72 \pm 0.23$ and $6.72 \pm 0.23$ respectively in the present study.

\section{Productive and reproductive performance}

Table 3 represents the productive and reproductive performance of Nageswari ducks under two different management practices. The average age at first egg (AFE) was $168.48 \pm 3.53$ days in Nageswari duck. It was observed that under farm condition ducks started laying earlier than those in farmer's house. The present findings on AFE are earlier than the reports of 
Morduzzaman et al. (2015) Bang. J. Anim. Sci. 44 (2): $92-99$

Table 1. Phenotypic features and their frequencies in Nageswari duck

\begin{tabular}{|c|c|c|c|c|c|}
\hline Phenotype & & Sex & $\mathrm{n}$ & Characteristic features & Frequency (\%) \\
\hline \multirow{15}{*}{$\begin{array}{l}\text { Plumage } \\
\text { color }\end{array}$} & \multirow{3}{*}{ Head color } & \multirow{2}{*}{ Male } & \multirow{2}{*}{26} & Black & 92.31 \\
\hline & & & & White spotted black & 7.69 \\
\hline & & Female & 32 & Black & 100 \\
\hline & \multirow{2}{*}{ Neck color } & Male & 26 & Black & 100 \\
\hline & & Female & 32 & Black & 100 \\
\hline & \multirow{4}{*}{ Breast color } & \multirow{2}{*}{ Male } & \multirow{2}{*}{26} & White & 84.62 \\
\hline & & & & Black & 15.38 \\
\hline & & \multirow{2}{*}{ Female } & \multirow{2}{*}{32} & White & 93.75 \\
\hline & & & & Black & 6.25 \\
\hline & \multirow{2}{*}{ Back color } & Male & 26 & Black & 100 \\
\hline & & Female & 32 & Black & 100 \\
\hline & \multirow{2}{*}{ Wing color } & Male & 26 & Black & 100 \\
\hline & & Female & 32 & Black & 100 \\
\hline & \multirow{2}{*}{ Tail color } & Male & 26 & Black & 100 \\
\hline & & Female & 32 & Black & 100 \\
\hline \multirow{5}{*}{ Bill color } & & \multirow{3}{*}{ Male } & \multirow{3}{*}{26} & Black & 57.69 \\
\hline & & & & Black with yellowish tint & 23.07 \\
\hline & & & & Yellowish & 19.23 \\
\hline & & \multirow{2}{*}{ Female } & \multirow{2}{*}{32} & Black & 93.75 \\
\hline & & & & Black with yellowish tint & 6.25 \\
\hline \multirow{2}{*}{ Bean color } & & Male & 26 & Black & 100 \\
\hline & & Female & 32 & Black & 100 \\
\hline \multirow{5}{*}{ Shank color } & & \multirow{3}{*}{ Male } & \multirow{3}{*}{26} & Black & 73.07 \\
\hline & & & & Black with yellowish tint & 7.69 \\
\hline & & & & Yellowish & 19.23 \\
\hline & & \multirow{2}{*}{ Female } & \multirow{2}{*}{32} & Black & 90.63 \\
\hline & & & & Black with yellowish tint & 9.37 \\
\hline \multirow{2}{*}{\multicolumn{2}{|c|}{ Skin color }} & Male & 26 & White & 100 \\
\hline & & Female & 32 & White & 100 \\
\hline \multirow{4}{*}{ Eye color } & & \multirow{2}{*}{ Male } & 26 & Black & 88.46 \\
\hline & & & 20 & Ash & 11.54 \\
\hline & & Female & 32 & Black & 84.37 \\
\hline & & & 52 & Ash & 15.62 \\
\hline & & Male & 26 & Black & 76.93 \\
\hline Web color & & Male & 20 & Black with yellowish tint & 23.07 \\
\hline ו & & Female & 32 & Black & 87.50 \\
\hline & & 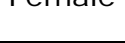 & 52 & Black with yellowish tint & 12.50 \\
\hline Egg color & & Female & 32 & Bluish & 100 \\
\hline
\end{tabular}

Islam et al. (2002); Sharma et al. (2003) and Zaman et al. (2005) in Nageswari ducks. Sharma et al. (2003) found average AFE to be $181.94 \pm 1.57$ days. In other studies, Zaman et al. (2005) and Islamet al. (2002) reported that average AFE of Nageswari duck was 188 days with a range of 174-198 days and 180-195 days respectively. This variation might be due to better nutrition and management condition. In the present study, total number of eggs laid per year ranged from 146 to 201 with a mean of $173.63 \pm 3.39$ eggs. This result is in accordance with the findings of Mahanta et al. (2001) and Islam et al. (2002) where they mentioned that the average egg production of Nageswari duck varied from 140-160. However, relatively lower egg number was found by Sharma et al. (2003) in same breed where the average egg number at 


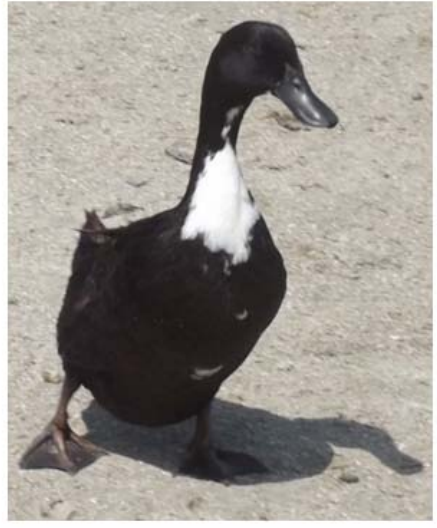

A

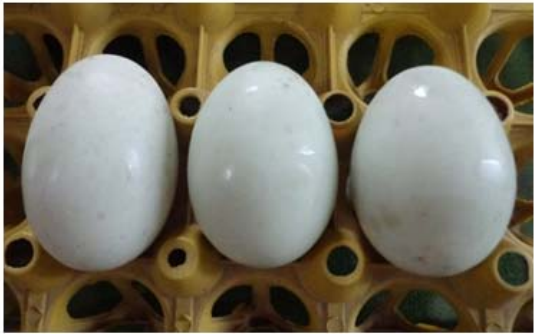

C

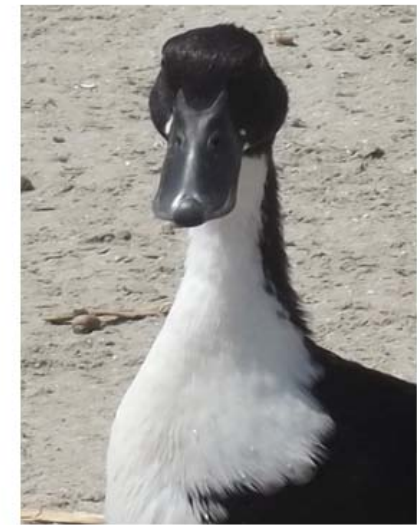

B

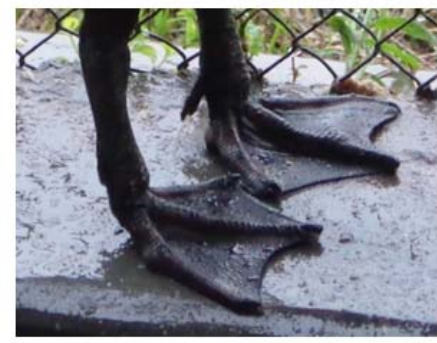

D

Figure 1. Different phenotypic features of Nageswari duck; A) Plumage color B) Snake deity head with black bill and bean C) Bluish tinge egg D) Shank and Web color

Table 2. Morphometric characteristics of Nageswari duck

\begin{tabular}{lcccccccc}
\hline \multirow{2}{*}{ Trait } & \multicolumn{4}{c}{ Male } & \multicolumn{4}{c}{ Female } \\
\cline { 2 - 9 } & $\mathrm{n}^{*}$ & Min & Max & Mean \pm SE & $\mathrm{n}$ & Min & Max & Mean \pm SE \\
\hline Body Weight $(\mathrm{kg})$ & 22 & 1.2 & 2.4 & $1.66 \pm 0.07$ & 27 & 1.2 & 2.1 & $1.51 \pm 0.05$ \\
\hline Body length $(\mathrm{cm})$ & 22 & 23.11 & 32.77 & $26.27 \pm 0.57$ & 27 & 20.83 & 29.21 & $23.79 \pm 0.39$ \\
\hline Head diameter $(\mathrm{cm})$ & 22 & 3.29 & 3.61 & $3.49 \pm 0.02$ & 27 & 2.91 & 3.71 & $3.36 \pm 0.04$ \\
\hline Bill length $(\mathrm{cm})$ & 22 & 5.33 & 7.11 & $5.87 \pm 0.09$ & 27 & 4.83 & 6.35 & $5.54 \pm 0.07$ \\
\hline Neck length $(\mathrm{cm})$ & 22 & 16.51 & 27.12 & $23.49 \pm 0.58$ & 27 & 15.75 & 25.85 & $21.59 \pm 0.49$ \\
\hline Shank length $(\mathrm{cm})$ & 22 & 4.57 & 6.60 & $5.76 \pm 0.12$ & 27 & 4.06 & 6.09 & $5.16 \pm 0.11$ \\
\hline Wing length $(\mathrm{cm})$ & 22 & 20.57 & 28.45 & $24.58 \pm 0.49$ & 27 & 18.54 & 26.67 & $21.99 \pm 0.53$ \\
\hline Massiveness & 22 & 4.79 & 10.27 & $6.33 \pm 0.28$ & 27 & 4.42 & 8.79 & $6.39 \pm 0.22$ \\
\hline Condition Index & 22 & 5.26 & 9.02 & $6.72 \pm 0.23$ & 27 & 5.25 & 9.24 & $6.93 \pm 0.23$ \\
\hline
\end{tabular}

${ }^{*} n=$ number of observations

Table 3. Productive and reproductive performances of Nageswari duck

\begin{tabular}{lccc}
\hline Trait & $\begin{array}{c}\text { On station } \\
(\text { Mean } \pm \text { SE) }\end{array}$ & $\begin{array}{c}\text { Farmer's level } \\
\text { (Mean } \pm \text { SE) }\end{array}$ & $\begin{array}{c}\text { Pooled average } \\
\text { (Mean } \pm \text { SE) }\end{array}$ \\
\hline Age at first egg (days) & $162.67 \pm 5.90(216)^{*}$ & $174.29 \pm 1.16(154)$ & $168.48 \pm 3.53$ \\
\hline Total number of eggs per year & $201.00 \pm 0.52(216)$ & $146.25 \pm 6.27(154)$ & $173.63 \pm 3.39$ \\
\hline Peak production of eggs (weeks) & $32.67 \pm 0.21(216)$ & $26.25 \pm 0.17(154)$ & $29.46 \pm 0.19$ \\
\hline Egg weight $(g)$ & $69.67 \pm 1.05(216)$ & $64.96 \pm 0.59(154)$ & $67.32 \pm 0.82$ \\
\hline Breeding ratio & $1.67 \pm 0.04(270)$ & $1.53 \pm 0.04(318)$ & $1.6 \pm 0.04$ \\
\hline
\end{tabular}

*values in parentheses indicate number of observations 
40,56 and 72 weeks of age were $64.62 \pm 0.34$, $85.54 \pm 0.40$ and $110.68 \pm 0.75$ eggs respectively. This might be due to malnutrition and poor management practices under extensive condition. In another study, Valavan et al. (2009) reported that average annual egg production was 200-220 in Nageswari duck under intensive management system which was higher than in the present study. Balanced nutrition, better management and selection over the years might be the attributing factors for higher egg production. In Chara and Chemballi ducks of Kerala, Mahantaet al. (1998) reported the egg number up to 72 weeks of age ( 8 laying cycles of 28 days each) as being 116.09 and 124.95 eggs respectively with peak production in 5th laying cycle which is lower than the present study. Genotypic difference might contribute for this variation.

Peak production averaged at $29.46 \pm 0.19$ weeks in the present investigation. The average egg weight was estimated as $67.32 \pm 0.82 \mathrm{~g}$ in the present study. Similar egg weight was reported by Sharma et al. (2002) in Nageswari duck and Mahanta et al. (2009) in Charachemballi duck of Assam where they reported the average egg weight of 62.45 and $71.6 \mathrm{~g}$ respectively. The average breeding ratio was found to be $1.6 \pm 0.04$. This result is similar to the findings of Zaman et al. (2005) and Islam et al. (2002) who reported male and female ratio of $1: 5$ in Nageswari duck. Mahanta et al. (2001) reported it as 1:6 in the same duck breed of Assam.

\section{Growth performance of Nageswari duck}

Weekly live weight data of Nageswari duck up to 12 weeks of age under intensive management system were recorded from the flock of BLRI and mean values are presented in the Table 4 . The mean live weight of day old duckling was found to be $33.98 \pm 2.28 \mathrm{~g}$. The average live weights at $1,2,3,4,5,6,7,8,10$ and 12 weeks of age were $123.21 \pm 17.77, \quad 263.16 \pm 40.00, \quad 438.92 \pm$ 57.64, 627.68 $\pm 73.68,797.68 \pm 85.54,974.73 \pm$ $119.44, \quad 1176.11 \pm 117.55, \quad 1251.90 \pm 111.28$, $1468.08 \pm 134.26$ and $1522.10 \pm 129.35 \mathrm{~g}$, respectively. To compare the growth performance of Nageswari duck with other available duck genetic resources average weekly live weight of three genotypes such as Pekin, Muscovy and Deshi white were collected from a published
Table 4. Growth performance of Nageswari ducks under intensive management system

\begin{tabular}{ccc}
\hline \multirow{2}{*}{ Age } & \multicolumn{2}{c}{ Live weight $(\mathrm{g})$} \\
\cline { 2 - 3 } & $\mathrm{N}$ & Mean $\pm \mathrm{SE}$ \\
\hline Day old & 63 & $33.98 \pm 2.28$ \\
$1^{\text {st }}$ week & 63 & $123.21 \pm 17.77$ \\
$2^{\text {nd }}$ week & 63 & $263.16 \pm 40.00$ \\
$3^{\text {rd }}$ week & 63 & $438.92 \pm 57.64$ \\
$4^{\text {th }}$ week & 63 & $627.68 \pm 73.68$ \\
$5^{\text {th }}$ week & 63 & $797.68 \pm 85.54$ \\
$6^{\text {th }}$ week & 63 & $974.73 \pm 119.44$ \\
$7^{\text {th }}$ week & 63 & $1176.11 \pm 117.55$ \\
$8^{\text {th }}$ week & 63 & $1251.90 \pm 111.28$ \\
$10^{\text {th }}$ week & 63 & $1468.08 \pm 134.26$ \\
$12^{\text {th }}$ week & 63 & $1522.10 \pm 129.35$ \\
\hline
\end{tabular}

paper of Bhuiyan et al. (2005) and is represented in Figure 2. It is showed that the day old weight was almost similar among the four different genotypes. After that a higher growth was observed in Nageswari duck up to 10 weeks of age as compared to Muscovy and Deshi white, while the highest growth performance was observed in meat type Pekin breed.Zaman et al. (2007) reported live weights at 0, 4, 8 and 12 weeks of age in male and female Nageswari ducks as $47.00 \pm 0.19,229.09 \pm 2.59$, $512.20 \pm 3.55$ and $895.79 \pm 5.04 \mathrm{~g}$, and $45.03 \pm$ $0.21,198.50 \pm 2.49,480.46 \pm 3.08$ and $863.10 \pm$ $4.31 \mathrm{~g}$ respectively under free range system of rearing in North Eastern India which is quite lower than the present findings. This variation might be due to the differences in feed availability, nutrients content in feed, management practices and selection response in Bangladeshi flock. In another investigation Islam et al. (2012) reported live weight of Khaki Campbell, Jinding and Deshi duck at 8 and 12 weeks of age in coastal region of Bangladesh as $492.25,514.25$ and $573.50 \mathrm{~g}$ and 643.00, 706.00 and $703.00 \mathrm{~g}$ respectively. Mahanta et al. (2009) recorded average body weight of Charachemballi ducks at 8 and 12 weeks under range condition in Assam as $715.02 \pm 5.16$ and $1054.63 \pm 10.27 \mathrm{~g}$ respectively. It is depicted from growth performance data of the present study and other reported findings that Nageswari duck is a heavier breed compared to other egg producingexotic breed (Khaki Campbell and Jinding) and Deshi ducks. 


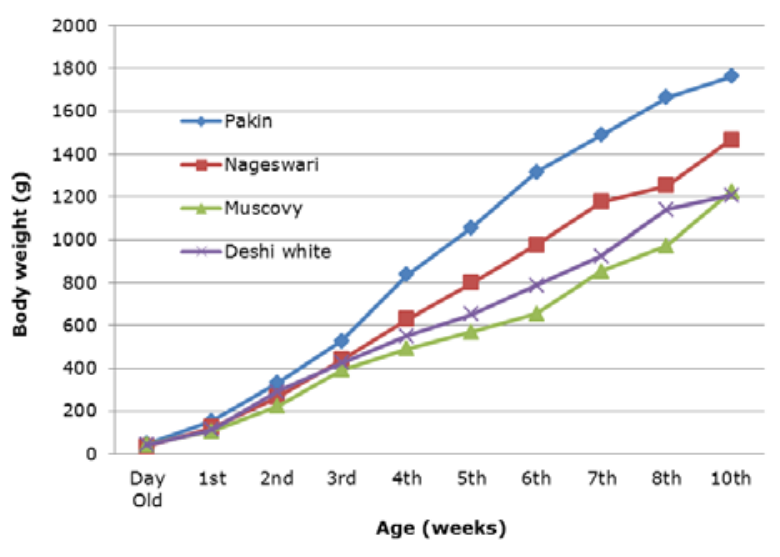

Figure 2. Growth performances of different duck breeds at different ages

\section{Conclusion}

The phenotypic, morphometric, productive and reproductive characteristics of Nageswari duck were unique from any other available common duck breeds/verities in Bangladesh. Present observation depicted that this breed is sporadically distributed with very low concentration in the districts of North Eastern regions of Bangladesh. Most of the farmers have been rearing this breed along with other available ducks which indicated potential genetic admixture. But there is no sufficient scientific documentation in this regard. However, it is the first report in Bangladesh using both on-station and on farm data to provide some precise facts on Nageswari ducks of Bangladesh. The findings of this study could be useful to characterize duck breed and prevent from genetic dilution through undertaking national conservation program.

\section{Acknowledgement}

The authors acknowledge the cooperation of farmers involved in Nageswari duck rearing and authority of CDBF and BLRI who provided valuable information related to this study.

\section{References}

BER (Bangladesh Economic Review) (2012). Ministry of Finance, Government of the People's Republic of Bangladesh, Dhaka. P. 92-93.

Bhuiyan MM, Khan MH, Khan MAH, Das BC, Lucky NS, Uddin MB (2005). A study on the comparative performance of different breeds of broiler ducks under farmer's condition at farming system research and development (FSRD) site, Sylhet, Bangladesh. International Journal of Poultry Science, 4:596-599.

Islam R, Mahanta JD, Barua N, Zaman G (2002). Duck farming in North-Eastern India (Assam). World's Poultry Science Journal, 8: 567-572.

Islam MN, Huque QME, Salahuddin M, Sarker MSK (2003). Potentiality of native genotypes of ducks. Proceedings of the $3^{\text {rd }}$ International Poultry Show and Seminar, WPSA-BB, 28 Feb-02 March 2003, Dhaka, Bangladesh, 3:25-29.

Islam MA, Khan MJ, Debi MR, Rahman MM (2012). Growth performance of three genotypes of ducks in coastal region of Bangladesh. Bangladesh Journal of Animal Science, 41: 19-23.

Khanum J, Chwalibog A, Huque KS (2005). Study on rural duck production systems in selected areas of Bangladesh. Livestock Research for Rural Development, 17: 113.

Mahanta JD, Ramakrishnan A, Jalaludeen A (1998). Egg production performance of two indigenous types of ducks in Kerala. Journal of Veterinary Animal Science,29: 30-35.

Mahanta JD, Sapcota D, Mili DC, Chakraborty A (2001). A survey of duck farming in Lakhimpur and Dhemaji districts of Assam. Indian Veterinary J ournal,6: 531-532.

Mahanta JD, Raj J, DekaSapcota D, Jalaludeen A (2009). Certain performance traits of Chara-chamballi ducks of Kelara under range condition in Assam. IV World Waterfowl Conference organized by Kerala Agricultural University, 11-13 November, 2009, Thrissur, India.

Murugan M, Gopinathan A, Sivakumar T (2009). Indigenous duck varieties in Utthiramerur block of north eastern agro climatic zone of Tamil Nadu. Proceeding of the IV World Waterfowl Conference organized by Kerala Agricultural University, 11-13 November, Thrissur, India, P. 74-76.

Rahman MM, Khan MJ, Chowdhury SD, Akbar MA (2009). Duck rearing system in southern 
Morduzzaman et al. (2015) Bang. J. Anim. Sci. 44 (2): $92-99$

coastal districts of Bangladesh. Bangladesh J ournal Animal Science, 38: 132-141.

Sharma SS, Zaman G, Goswami RN, Mahanta JD (2003). Certain performance traits of Nageswari ducks of Assam under range condition. Indian Journal of Animal Science, 73: 831 - 832.

Sharma SS, Zaman G, Goswami RN, Roy TC, Mahanta JD (2002). Physical characteristics of Nageswari duck eggs of Assam. Indian J ournal of Animal Science, 72: 1177-1178.

Valavan SE, Kumar TS, Vengadabady N, Mani K, Edwin SC, Bharathidhasan A (2009). Duck production system in Tamil Nadu. Proceeding of the $4^{\text {th }}$ world waterfowl conference, 11-13 November, organized by
Kerala Agricultural University, Thrissur, India, P. 291-298.

Vij PK, Tantia MS, Pan S, Vijh RK (2010). Morphometric and egg characteristics of indigenous ducks. Journal of Livestock Biodiversity, 2: 77-80.

Zaman G, Goswami RN, Aziz A, Nahardeka N, Roy TC, Mahanta JD (2005). Farming system of Nageswari ducks in NorthEastern India (Assam). World's Poultry Science Journal, 61: 687-693.

Zaman G, Goswami RN, Aziz A, Nahardeka N, Mahanta JD (2007). Studies on body weight and shank length of Nageswari duck of Assam. Indian Journal of Poultry Science, 42: 79-80. 